\title{
Laboreal
}

Volume $6 \mathrm{~N}^{\circ} 2$ | 2010

Varia

\section{Análise do trabalho, formação contextualizada e acção de transformação das condições de trabalho no sector de saneamento de um serviço municipal}

Análisis del trabajo, formación contextualizada y acción de transformación de las condiciones de trabajo en el sector de saneamiento de un servicio municipal Analyse du travail, formation contextualisée et action de transformation des conditions de travail dans un secteur d'assainissement d'un service municipal Work analysis, contextualized training and actions to change working conditions in the sanitation sector of a municipalized service

\section{Cláudia Costa e Catarina Silva}

\section{OpenEdition}

\section{Journals}

\section{Edição electrónica}

URL: http://journals.openedition.org/laboreal/8768

DOI: $10.4000 /$ laboreal. 8768

ISSN: 1646-5237

Editora

Universidade do Porto

Refêrencia eletrónica

Cláudia Costa e Catarina Silva, « Análise do trabalho, formação contextualizada e acção de transformação das condições de trabalho no sector de saneamento de um serviço municipal », Laboreal [Online], Volume 6 NN$^{\circ} 2$ | 2010, posto online no dia 01 dezembro 2010, consultado o 10 outubro 2019. URL : http://journals.openedition.org/laboreal/8768; DOI : 10.4000/laboreal.8768

Este documento foi criado de forma automática no dia 10 outubro 2019.

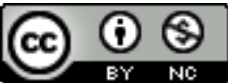

Laboreal está licenciado com uma Licença Creative Commons - Atribuição-NãoComercial 4.0 Internacional. 


\section{Análise do trabalho, formação contextualizada e acção de transformação das condições de trabalho no sector de saneamento de um serviço municipal}

Análisis del trabajo, formación contextualizada y acción de transformación de las condiciones de trabajo en el sector de saneamiento de un servicio municipal Analyse du travail, formation contextualisée et action de transformation des conditions de travail dans un secteur d'assainissement d'un service municipal Work analysis, contextualized training and actions to change working conditions in the sanitation sector of a municipalized service

Cláudia Costa e Catarina Silva

\section{NOTA DO EDITOR}

Manuscrito recebido em : Setembro/2010

Aceite após peritagem : Novembro/2010

\section{Introdução}

\subsection{Análise-formação-acção : um rumo para a prevenção}

Desde a Directiva-Quadro 89/391/EC, transposta para o normativo interno pelo Decreto Lei $\mathrm{n}^{\circ}$ 441/91 de 14 de Novembro, que vários instrumentos legais têm vindo a estabelecer orientações e prescrições no âmbito da prevenção dos riscos profissionais. 
No entanto, aquilo que se verifica na prática, em numerosos contextos profissionais, reflecte uma perspectiva formal do conceito de prevenção : consistindo, por parte das empresas, na implementação estrita das leis e, por parte dos operadores, na adesão às regras definidas pelo enquadramento legal ou regulamentar local. Alguns estão convictos que o cumprimento destas imposições por ambas as partes é suficiente para garantir a segurança e a saúde dos trabalhadores. Porém, consideramos esta perspectiva perniciosa, na medida em que parte do princípio (a nosso ver errado) de que as empresas funcionam em circunstâncias estáveis e ideais - quando a realidade é sempre bem diferente - e, nesse cenário, o incumprimento de regras por parte dos operadores é frequentemente encarado como um comportamento negligente - quando na maioria das vezes até superam as lacunas de funcionamento da empresa (Bourrier, 1998, 2001). Consideramos que a prevenção não deve ser concebida como algo que pode estar à priori totalmente definido e organizado e que se impõe, mas antes como algo que se edifica no quotidiano real de trabalho, na organização da (inter)acção dos operadores (Benchekroun, Bourgeois, Hubault, 2002 ; Ré, 2006 ; Vasconcelos, Duarte \& Moreira, 2010).

2 Recusamos liminarmente a perspectiva, exclusivamente, normativa ou política da prevenção. Privilegiamos uma perspectiva compreensiva desenvolvida a partir de abordagens formativas alicerçados na inteligência do trabalho real e no reconhecimento do papel que os diferentes agentes do trabalho podem ter em processos de concepção/mudança, que visem a prevenção e a promoção da saúde e segurança. Portanto, a abordagem formativa que defendemos não tem por único objectivo instruir quanto às regras aplicáveis, embora esta seja a finalidade de muitas formações profissionais em matéria de segurança. Ela afirma-se como uma plataforma de discussão e compreensão da actividade de trabalho e dos seus riscos em termos de saúde e segurança, de análise e enquadramento de diferentes tipos de regras (formais e informais) e de debate e avaliação da exequibilidade das acções concretas que visem a melhoria das condições de trabalho.

3 Assim, a nossa abordagem tem três facetas que se articulam : análise-formação-acção. A formação profissional contínua emerge como elemento agregador. A análise ergonómica do trabalho (AET) assume-se como instrumento de conhecimento da actividade de trabalho, não só prévio ao estabelecimento do programa de formação (permitindo definir os conteúdos-alvo), mas também simultâneo ao desenvolvimento do próprio processo formativo (permitindo retrabalhar episódios, acontecimentos excepcionais, etc.). A acção de transformação é uma consequência quer do próprio processo (in)formativo, quer das análises anteriores, numa dupla perspectiva: transformação das representações dos agentes participantes sobre o trabalho e transformação das condições e modos de exercício da actividade de trabalho.

4 Convém reforçar que ao associarmos numa mesma abordagem a análise do trabalho, a formação profissional e a acção de transformação estamos inevitavelmente a apelar à participação oportuna de diferentes agentes do trabalho (operadores, chefias intermédias e de topo, elementos da saúde ocupacional ou outros).

5 Esta perspectiva da formação tem as suas raízes na tradição da “ergonomia da actividade ", seguindo orientações semelhantes às de alguns projectos da psicologia do trabalho, que se preocupam com a "transformação das condições da realização da actividade real de trabalho e com o reconhecimento do papel que o trabalhador assume na sua organização" (Vasconcelos, Duarte \& Moreira, 2010, p. 543). Neste sentido, os 
processos formativos, são tidos como processos de desenvolvimento humano e não simplesmente, como já foi dito, momentos de transmissão de um conjunto de instruções que se querem ver cumpridas. Assim, na concepção dos processos formativos deve-se considerar as capacidades de aprendizagem do adulto (Paumés \& Marquié, 1995) e promover práticas pedagógicas que não negligenciem os saberes, a experiência e vivência profissional reconhecidos através da análise da actividade de trabalho (Lacomblez, Santos \& Vasconcelos, 1999 ; Massena, 2006).

6 A ancoragem do processo formativo ao trabalho real promove a articulação entre "momentos de auto-análise guiada da actividade de operadores (...), em posto de trabalho, com momentos em que os seus resultados são partilhados e discutidos num grupo de pares, mas onde estão também representados outros actores "relativamente pertinentes" para as actividades e os problemas em discussão (...) assim como para o esboçar de soluções possíveis e organizacionalmente congruentes." (Lacomblez \& Vasconcelos, 2009, p. 57).

7 O estudo que apresentamos (Costa, 2010) insere-se nesta lógica de articulação da análise do trabalho, formação e acção de melhoria das condições de trabalho, integrando actores com estatutos e poderes diferentes.

\subsection{Argumentos para um projecto de análise-formação-acção no sector do saneamento}

8 A actividade de trabalho no sector do saneamento apresenta particularidades no que respeita a riscos físicos, químicos e biológicos, que podem atentar contra a segurança e saúde dos trabalhadores, sendo por isso reconhecida como uma actividade de risco. $\mathrm{O}$ regulamento de segurança, higiene e saúde no trabalho na exploração dos sistemas públicos de drenagem de águas residuais (Portaria ํำ62/2002), aponta como factores de risco específicos :

- a insuficiência de oxigénio atmosférico : nas estruturas subterrâneas, incluindo colectores, devido a não existirem trocas de ar com o exterior, ou destas serem reduzidas, a concentração de oxigénio pode ser reduzida.

- a existência de gases e vapores perigosos : devido à insuficiência de oxigénio podem formarse e/ou acumular-se gases tóxicos e inflamáveis normalmente, "consequência das reacções de oxidação dos compostos orgânicos e inorgânicos, bem como da diluição do volume de ar no volume de gases produzidos" (NOHSC, 1995, in Correia, 2002, p. 71). "Os gases susceptíveis de constituir risco de intoxicação, asfixia, incêndio, ou explosão, são o ozono, o cloro, o gás sulfídrico, o dióxido de carbono, e o metano" (art. 6º, Port. 762/2002, p. 5124).

- contacto com reagentes, águas residuais ou lamas: na rede de saneamento existem condições propícias ao desenvolvimento de agentes de doença, tais como a humidade relativa elevada, ausência de vento ou circulação natural do ar e a pouca luminosidade. Os agentes de risco biológico são bactérias, vírus, parasitas e fungos, responsáveis nomeadamente por doenças do foro gastrointestinal e respiratório.

- aumento brusco de caudal e inundações súbitas : o risco de afogamento está associado a alguns trabalhos na rede de saneamento. Em caixas visitáveis, no espaço visitável, o aumento súbito do volume de água de caudais drenados, devido a uma falha ao nível do dispositivo de controlo de escoamento gera risco de afogamento por inundação da própria caixa (Correia, 2002). 

às suas repercussões graves, muitas das vezes com danos irreparáveis para a saúde do trabalhador, têm destaque nos órgãos da comunicação social. A Estratégia Nacional para a Segurança e Saúde no Trabalho, 2008-2012 (Resolução do Concelho de Ministros no 59/008) coloca ênfase na diminuição dos acidentes de trabalho, tornando-se necessário desenvolver e aperfeiçoar metodologias de avaliação dos riscos profissionais, de participação e formação dos trabalhadores.

Desde 2001 que nos SMAS Oeiras e Amadora se registam acidentes no grupo profissional varejadores resultantes de quedas de materiais, projecção de materiais e/ou equipamentos, gerando situações de traumatismos ao nível dos membros inferiores no decorrer dos trabalhos efectuados na via pública. No ano de 2007 registaram-se 4 acidentes de trabalho no manuseamento de mangueiras, gerando lesões na coluna lombar (figura 1).

Figura 1 - Acidentes de trabalho por função em 2007 (em valores absolutos) (in Divisão de Gestão de Recursos Humanos, 2008).
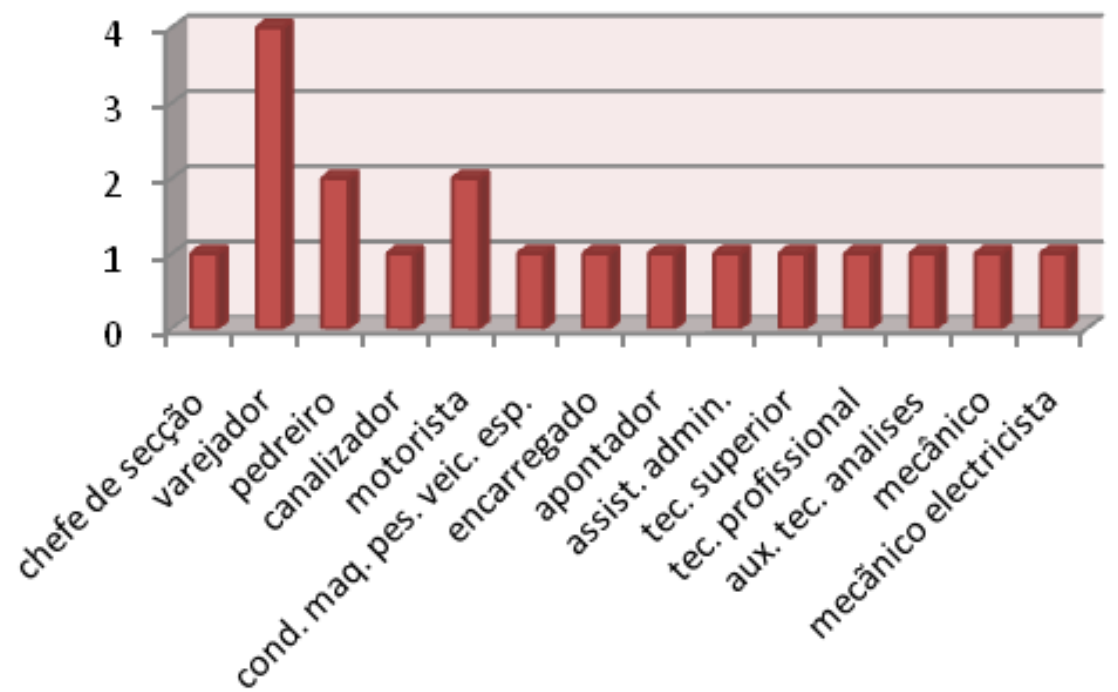

Os investimentos em formação na categoria sócio-profissional operária, onde se inserem os varejadores, no período entre 2005-2007, revelaram-se incipientes face ao investimento global no conjunto dos efectivos dos SMAS de Oeiras e de Amadora (tabela 1).

12 Apesar de no ano de 2007 se verificar um aumento considerável da participação dos operadores, da categoria sócio-profissional operária, em acções de formação, estes constituem apenas $7,1 \%$ do total de participantes. A formação destes operadores incidiu maioritariamente em acções de "Condução Defensiva".

13 Tabela 1 - Número de participações dos trabalhadores dos SMAS Oeiras Amadora em formação (em valores absolutos) (in Divisão de Gestão de Recursos Humanos, 2007).

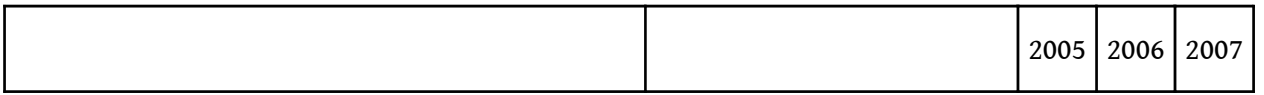




\begin{tabular}{|l|l|l|l|l|}
\hline \multirow{2}{*}{ Efectivos } & Total & 453 & 445 & 429 \\
\cline { 2 - 6 } & Participações em formações & 108 & 404 & 649 \\
\hline \multirow{2}{*}{ Efectivos da categoria sócio-profissional operária } & Total & 113 & 109 & 104 \\
\cline { 2 - 6 } & Participações em formações & 2 & 10 & 46 \\
\hline
\end{tabular}

Deste modo, torna-se essencial definir regras que contribuam para a segurança e saúde dos trabalhadores e para a correcta utilização dos equipamentos, quer em funcionamento normal quer em situações de emergência. Mas, no sentido de contribuir para o êxito da implementação dessas regras devem ser estruturados processos formativos que permitam discuti-las e enquadrá-las nos respectivos contextos e actividades de trabalho. Trata-se pois de estruturar processos que se afastam dos modelos de formação mais tradicionais (de tipo exclusivamente expositivo e prescritivo), na medida em que tomam em consideração as condições reais de exercício da actividade de trabalho e a experiência profissional dos operadores, proporcionam a partilha dos conhecimentos e saberes-fazer entre os participantes e constituem o ponto de partida de processos de transformação (Lacomblez \& Teiger, 2007).

Nesta perspectiva, é importante também considerar que muitos dos conhecimentos que se difundem no seio dos colectivos de trabalho, de modo informal, por contiguidade de postos de trabalho ou de funções, por transmissão de viva voz dos mais antigos para os mais novos, acabam por constituir regras de trabalho não-escritas, às quais os seus elementos devem aderir para poderem estar integrados (de Terssac 2002). Estas regras de trabalho elaboradas pelos colectivos, frequentemente, não são reconhecidas por parte das chefias como fundamentais, quer para a organização da actividade individual e colectiva, quer como estruturas a partir das quais se pode, definitivamente, contribuir para a constituição de novos saberes e implementação de regras mais ajustadas do ponto de vista da segurança e saúde no trabalho (Girin \& Grosjean, 1996).

Face às orientações da Estratégia Nacional para a Segurança e Saúde no Trabalho, 2008-2012 e aos factos referidos anteriormente, nomeadamente, (i) os factores de riscos específicos dos sistemas públicos de drenagem de águas residuais, (ii) a distribuição dos acidentes de trabalho nos Serviços Municipalizados (iii) a evidência dos acidentes graves ocorridos nas actividades de exploração dos sistemas de águas residuais (iv) e a ausência da formação centrada na segurança, a Divisão de Gestão de Recursos Humanos (DGRH) dos SMAS de Oeiras e Amadora assumiu como uma prioridade o desenvolvimento de um projecto de formação centrado na promoção da segurança e saúde dos operadores daquele sector.

17 Assim, o projecto aqui apresentado teve como objectivo geral contribuir para o desenvolvimento de competências no âmbito da Segurança, recorrendo a um processo metodológico de análise-formação-acção, contextualizada, num grupo de operadores da área do saneamento dos Serviços Municipalizados de Água e Saneamento de Oeiras e de Amadora e seus responsáveis. Sendo um projecto que abraça também a componente de acção decorre dela o objectivo de melhorar as condições de exercício da actividade de trabalho que se considerem desajustadas para prática das competências adquiridas. 


\section{Metodologia}

\subsection{Contexto estudado}

18 Os SMAS de Oeiras e Amadora prestam serviço de abastecimento de água e saneamento básico às populações residentes e agregam geograficamente dois concelhos, o de Oeiras e o da Amadora, promovendo a manutenção e remodelação de redes de água e saneamento básico.

O estudo que apresentamos neste artigo foi desenvolvido na Divisão de Saneamento de Oeiras (DSO), em concreto no sector de Redes de Saneamento, onde se considerou prioritário a adopção de medidas de carácter preventivo no domínio da Higiene, Segurança e Saúde no Trabalho (HSST), relativamente às actividades desenvolvidas pelos varejadores na rede de saneamento (conservação e assistência de redes e ramais de esgotos domésticos e pluviais).

Deste modo, as funções atribuídas à profissão de varejador são a limpeza e a desobstrução da rede de colectores de águas residuais domésticas e pluviais, ramais domiciliários e caixas de visita, assegurando o bom funcionamento da rede de esgotos dos municípios em questão.

\subsection{População alvo e amostra}

21 De uma população-alvo constituída por 29 operadores do sexo masculino, participaram no estudo 6 operadores do serviço geral da Divisão de Saneamento de Oeiras. Esta amostra foi escolhida, devido: (i) a ser o grupo que efectua todo o tipo de trabalho adstrito a esta Divisão, (ii) aos seus horários, que permitem uma maior disponibilidade, dentro do horário de trabalho, para frequentar acções de formação colectiva em sala, e (iii) às suas características biográficas (idade, antiguidade na função e habilitações académicas) não diferirem das características da população alvo.

22 A idade média deste conjunto de seis operadores é de 47 anos, com desvio padrão de 11,8 , e a antiguidade média é de 19 anos com desvio padrão de 6,7 anos. A este grupo correspondem igualmente habilitações académicas baixas ( 3 operadores com o $4^{\circ}$ ano e 3 com o 9a ano).

\subsection{Abordagem metodológica} (análise da actividade de trabalho pelos operadores, focando-se nas sequências operacionais, nas suas determinantes/condicionantes e nas suas consequências) apoiadas durante o trabalho e sessões de análise e discussão colectiva, em torno de situações-problema, com recurso à análise de registos vídeo e fotografias da actividade de trabalho. 
A terceira etapa correspondeu à implementação do processo formativo.

A quarta etapa, consistiu no primeiro momento de análise tomando como referência o conteúdo das sessões de formação. Temporalmente distanciado - quinta etapa decorreu o segundo momento de avaliação, consistindo na reavaliação das características da situação de trabalho, após a implementação das propostas de transformação emergentes na terceira etapa.

\subsubsection{Primeira etapa : conhecer o trabalho real}

As técnicas utilizadas na primeira etapa do estudo consistiram na observação aberta, com recurso a registo vídeo e no registo de verbalizações dos operadores. Estas técnicas foram usadas durante as duas visitas aos locais de trabalho, acompanhando a jornada diária, com o objectivo de conhecer as actividades desenvolvidas pelo nosso grupo de operadores. Tratando-se de uma observação aberta procurámos conhecer sequências operacionais relativas às diferentes tarefas, as posturas mais utilizadas, os riscos/ constrangimentos associados às características do contexto de trabalho (via pública, terreno privado ou baldio, espaço confinado, etc.), os constrangimentos ou limitações impostas pelo uso dos equipamentos, máquinas e equipamentos de proteç̧ão individual. Durante a observação da situação de trabalho foram realizadas filmagens, procurando registar estes aspectos. A observação incidiu sobre a actividade de inspecção e desobstrução/limpeza das redes/sistemas de saneamento, incluindo fossas sépticas domésticas. De modo a complementar o nosso conhecimento sobre este sector de actividade realizou-se uma pesquisa documental nos registos existentes nos SMAS Oeiras e Amadora e em publicações relativas aos sistemas de saneamento.

Os dados provenientes das observações, dos registos das verbalizações e dos vídeos foram tratados de modo a nos permitir construir um cenário descritivo do que consiste a actividade de trabalho no sector do saneamento e dos riscos a ela associados.

Esta etapa culminou com a elaboração de um pré-diagnóstico da situação de trabalho, essencial à concepção de um processo formativo ajustado às necessidades dos operadores.

\subsubsection{Segunda à quarta etapa : elaboração, implementação e primeiro momento de análise do processo formativo}

1 A segunda etapa do presente estudo consistiu na elaboração do processo formativo com base na caracterização da situação de trabalho (primeira etapa) e considerando as características dos participantes (idade e escolaridade). Planificámos um processo formativo em regime de alternância entre diferentes tipos de sessões, (i) sessões teóricas expositivas, em sala sobre a segurança na actividade de saneamento, (ii) sessões individuais de análise guiada da actividade de trabalho no posto de trabalho, (iii) sessões de discussão colectiva dos resultados das sessões de formação anteriores e dos vídeos realizados na primeira etapa (reflexão colectiva assistida por vídeo).

Para estruturarmos o processo formativo recolhemos e analisámos informações relativas: (i) à organização dos horários e à planificação das actividades de saneamento; (ii) às regras de segurança aplicáveis ao sector em estudo; e (iii) à caracterização da actividade de trabalho. Para além da pesquisa e análise documental sobre a temática, foram analisadas e seleccionadas as imagens anteriormente 
recolhidas no decurso das visitas realizadas, na primeira etapa, aos locais de trabalho, possibilitando a escolha das situações-problema e cenários chave para o desenvolvimento da discussão colectiva em sala.

A carga horária proposta para o desenvolvimento de cada sessão foi encarada como uma referência, existindo liberdade para uma gestão do tempo de acordo com as características do grupo e com os recursos existentes. No decurso da implementação da formação - terceira etapa - foi necessário estar-se atento às motivações dos operadores, de modo a gerir eficazmente as sessões. As sessões em sala de formação tiveram no máximo até 2 horas e foram alternadas com sessões de auto-análise do trabalho com a duração de uma manhã, aproximadamente 4 horas.

O processo formativo teve um total de nove sessões. Oito decorreram durante um período de duas semanas, entre o dia 17 de Setembro de 2008 e o dia 3 de Outubro de 2008. Estas sessões foram realizadas com intervalos, de no máximo 3 dias, e realizadas logo no início do dia de trabalho, ou seja, a partir das 8 horas da manhã. A nona sessão, de apresentação aos responsáveis da Organização do balanço da formação e das propostas de melhoria das condições de trabalho, foi realizada no dia 20 de Outubro de 2008.

A estrutura das sessões de formação é apresentada na tabela 2. Com esta estrutura pretendeu-se que o operador atingisse os seguintes objectivos específicos: (i) identificar os riscos específicos associados às actividades realizadas; (ii) identificar as causas dos (quase) acidentes de trabalho; (iii) adquirir competências de acção no âmbito da sua segurança no trabalho.

Tabela 2 - Caracterização das sessões de formação.

\begin{tabular}{|c|c|c|c|c|}
\hline Ordem & Tema & Tipo de sessão & Contexto & $\begin{array}{l}\text { Duração } \\
\text { (h) }\end{array}$ \\
\hline 1 & $\begin{array}{l}\text { Segurança e saúde } \\
\text { ocupacional }\end{array}$ & Introdução & $\begin{array}{ll}\text { Sala de } \\
\text { aula }\end{array}$ & 2 \\
\hline 2 & & Auto-análise do trabalho & $\begin{array}{l}\text { De } \\
\text { trabalho }\end{array}$ & 4 \\
\hline 3 & Espaços confinados & Discussão colectiva & $\begin{array}{ll}\text { Sala de } \\
\text { aula }\end{array}$ & 2 \\
\hline 4 & & Discussão colectiva & $\begin{array}{ll}\text { Sala de } \\
\text { aula }\end{array}$ & 2 \\
\hline 5 & \multirow{3}{*}{$\begin{array}{l}\text { Posturas e manuseamento } \\
\text { manual de cargas }\end{array}$} & Discussão colectiva & $\begin{array}{ll}\text { Sala de } \\
\text { aula }\end{array}$ & 2 \\
\hline 6 & & Auto-análise do trabalho & $\begin{array}{l}\text { De } \\
\text { trabalho }\end{array}$ & 4 \\
\hline 7 & & Discussão colectiva & $\begin{array}{ll}\text { Sala de } \\
\text { aula }\end{array}$ & 2 \\
\hline
\end{tabular}




\begin{tabular}{|c|c|c|c|c|}
\hline 8 & \multirow{2}{*}{$\begin{array}{l}\text { Desenvolvimento e } \\
\text { Negociação de Propostas }\end{array}$} & Análise do processo de formação & $\begin{array}{ll}\text { Sala } & \text { de } \\
\text { aula } & \end{array}$ & 2 \\
\hline 9 & & $\begin{array}{l}\text { Apresentação e negociação de } \\
\text { propostas (com a participação dos } \\
\text { responsáveis) }\end{array}$ & $\begin{array}{ll}\text { Sala de } \\
\text { aula }\end{array}$ & 2 \\
\hline 10 & \multirow{2}{*}{ Avaliação } & Auto-análise do trabalho & $\begin{array}{l}\text { De } \\
\text { trabalho }\end{array}$ & 4 \\
\hline 11 & & Discussão colectiva & $\begin{array}{ll}\text { Sala de } \\
\text { Aula }\end{array}$ & 2 \\
\hline
\end{tabular}

Todas as sessões de formação realizadas foram registadas em vídeo e transcritos os diálogos para um documento de texto, designado de protocolo verbal (Bisseret, Sebillote \& Falzon, 1999). Este documento foi objecto de análise - quarta etapa. Esta análise consistiu na organização e tratamento do conteúdo do protocolo verbal em função dos temas abordados pelos operadores nas sessões, são eles: os recursos humanos, os recursos materiais, os procedimentos de trabalho e a formação. Para cada um destes temas foram identificados os modos de discurso utilizados pelos participantes, a partir da adaptação da taxonomia apresentada por Vilar de Melo (1999, in Vergnaud 2001), num trabalho realizado com sindicalistas.

Classificámos os modos de discurso nas seguintes categorias :

- Modo Constantivo - enunciado traduzindo a simples constatação, descrição ou caracterização de factos e acontecimentos relativos à situação de trabalho ;

- Modo Imperativo - enunciado relativo a uma ordem, de indicação daquilo que convém fazer ou não fazer em relação à situação de trabalho ;

- Modo Axiológico - enunciado emitindo uma opinião, um juízo de valor, um conselho sobre um facto ou acontecimento na situação de trabalho ;

- Modo Explicativo - enunciado destinado a mostrar as razões de um facto ou acontecimento ;

- Modo Condicional - enunciado que liga argumentos entre si, seja acções a condições ;

- Modo Interrogativo - pergunta colocada ao formador ou a um par seja para obter uma explicação, seja para o provocar.

Após identificar os modos de discurso de cada unidade com significado do protocolo verbal e o respectivo tema desenvolveu-se um tratamento estatístico descritivo (frequências relativas). Os dois eixos de tratamento dos dados (temas $\mathrm{x}$ modos de discurso) permitiram-nos perceber como os operadores se posicionaram face aos diferentes problemas identificados na sua situação de trabalho e como evoluiram no modo de os abordar no decurso do processo formativo.

\subsubsection{Quinta etapa : segundo momento de análise do processo formativo}

39 A quinta etapa do presente estudo, corresponde ao segundo momento de avaliação. Decorrendo temporalmente distanciado, consiste em reavaliar as características da situação de trabalho. Deste modo, esta etapa teve como objectivo identificar as transformações existente nas condições de trabalho e nos procedimentos de segurança, tomando como referência a análise da actividade realizada na etapa 1. 
Assim, passados sete meses (Maio de 2009) foi realizada uma nova visita ao contexto de trabalho tendo como objectos de análise os procedimentos e estratégias de trabalho utilizados e as próprias condições de trabalho. As técnicas metodológicas utilizadas para este efeito consistiram na observação, com recurso a registo de vídeo, e no registo de verbalizações dos operadores.

41 Seguidamente realizou-se uma nova sessão de formação em sala, a décima primeira sessão (vd. tabela 2), tendo como ponto de partida os dados contextuais relativos aos diferentes momentos de análise do trabalho e as informações provenientes das unidades orgânicas competentes sobre o estado de implementação das propostas transformação das condições de trabalho. A sessão foi organizada em duas partes. A primeira parte foi orientada para a análise das medidas já implementadas pelos SMAS, suas repercussões no desenrolar da actividade de trabalho, em geral, e na segurança, em particular. A segunda parte, orientada para a análise das mudanças nas estratégias e procedimentos de segurança, teve como mote de discussão a análise de dois filmes da mesma actividade de trabalho, realizados em momentos diferentes, um antes e um pós a realização das sessões de formação. Estiveram presentes nessa sessão todos os operadores que participaram nas sessões de 1 a 8 (vd. tabela 2). Esta sessão foi gravada em suporte áudio, posteriormente foi transcrita e feita a análise descritiva do seu conteúdo.

Foram, também, reanalisados os traços gerais da actividade, nomeadamente a sinistralidade no sector de saneamento. Para este efeito recolheu-se informação documental junto dos serviços competentes dos SMAS.

\section{Da análise da actividade de trabalho ao projecto formativo}

\subsection{Características da actividade de trabalho no sector do saneamento}

43 As actividades principais dos varejadores e dos operadores em obras na rede são a inspecção, limpeza e manutenção de colectores, caixas de visita e ramais de ligação, limpeza de fossas sépticas, e trabalhos de abertura de valas.

Todos os trabalhos efectuados pelos varejadores na via pública apresentam perigos associados.

Assim a exposição a condições climatéricas, por vezes adversas, pode conduzir tanto a insolações como a constipações e gripes. Para além dos efeitos directos na saúde, referidos anteriormente, a exposição a climas adversos, induz também a efeitos indirectos, como por exemplo, o aumento da susceptibilidade a lesões músculoesqueléticas, "stress", fadiga e desconforto no desempenho das suas funções.

Outro perigo inerente aos trabalhos na via pública é a concomitante circulação rodoviária, se associada a uma deficiente sinalização dos trabalhos (onde decorrem os trabalhos de reparação ou limpeza e manutenção da rede), que aumenta o risco de ocorrência de atropelamento, choque ou despiste e danos materiais. A figura 2 ilustra o que acabamos de referir, apelando para a necessidade do uso correcto e regular dos equipamentos de protecção colectiva, como sejam as vedações ou gradeamento (figura 2B) e sinalização (vertical) (figura 2C) - Decreto Regulamentar $n^{0} 33 / 88$ de 12 de 
Setembro - sinalização temporária de obras e obstáculos na via pública. Junto com a sinalização das operações, a sinalização dos trabalhadores (colete reflector) (figura 2A) são medidas de prevenção essenciais, mesmo em trabalhos esporádicos e/ou pouco demorados.

Figura 2. - Equipamentos de protecção individual e colectiva : A - sinalização dos trabalhadores ; B - equipamentos de protecção colectiva ; C - sinalização vertical. condutores e dos utentes do serviço, podendo gerar interferências no normal desenrolar espácio-temporal do trabalho e na implementação dos sistemas de segurança adequados à situação. Esta situação é particularmente visível nas intervenções não planeadas, as chamadas urgências.

49 Em relação aos materiais utilizados verifica-se a necessidade de manobrar equipamentos bastante pesados (pá de caleira, mangueiras, picareta), pelo que poderemos deparar-nos com o risco aumentado de lesões músculo-esqueléticas se as posturas adoptadas não forem as mais adequadas do ponto de vista biomecânico. Ao uso de equipamentos pesados associa-se o facto de a localização da zona principal de actividade ser frequentemente junto ao solo, dificultando a adopção de posturas biomecanicamente correctas, repercutindo-se em sobrecargas a nível da coluna dorsal e lombar. A figura 3(A e B) mostra as posturas adoptadas por estes profissionais.

50 As características da zona principal de trabalho (dimensões reduzidas, visibilidade limitada e localização no solo) dificulta a formação de duplas de operadores, com o objectivo de partilharem a carga de trabalho. Por este motivo a situação mais comum é a distribuição de tarefas pelos elementos do grupo.

Figura 3. - Posturas adoptadas nas actividades de : A - aberturas de tampas ; B - limpeza de fossas sépticas.

$51 \quad$ A B

52 A fadiga resultante de um esforço muscular estático, tal como o transporte e elevação manual de cargas (Decreto-Lei nㅜ30/93, de 25 de Setembro transpõe a Directiva nº0/269/CEE - prescrições mínimas de segurança e de saúde na movimentação manual de cargas) pode interferir na eficiência e conduzir a acidentes como queda de objectos sobre os pés (por exemplo, ferramentas, tampas de esgoto, etc.), ferimentos ocasionados por choques ou pancadas, contusões e lesões lombares.

53 A manipulação de equipamentos eléctricos, com o objectivo de aligeirar certos procedimentos de trabalho, nas obras nos sistemas de saneamento de águas residuais valas ou câmaras de visita - apresenta risco de choque eléctrico, pelo que é de maior importância a ligação à terra dos mesmos.

54 Estão associados a este sector de actividade riscos específicos que se não forem avaliados e controlados potenciam a ocorrência de acidentes graves que podem provocar danos irreparáveis nos operadores, que lembramos : (i) o risco de afogamento pelo aumento súbito do caudal de águas residuais, (ii) o risco químico pela presença de gases tóxicos e carência de oxigénio, e (iii) o risco biológico através da presença de bactérias, vírus, parasitas e fungos. 
55 Em síntese a actividade de trabalho no sector do saneamento caracteriza-se por uma enorme exposição constrangimentos ambientais - ruído, poeiras e gases, temperaturas extremas, agentes biológicos - a constrangimentos físicos - posturas penosas, esforços físicos intensos, manuseamento de cargas - e a constrangimentos relacionais derivados da exposição pública da actividade de trabalho aos transeuntes, condutores e utentes.

\subsubsection{Actividade de inspecção e desobstrução/limpeza das redes/sistemas de saneamento}

56 Após verificação da anomalia reclamada (em que as situações mais correntes são entupimentos por obstruções ou assoreamento) é necessário proceder-se à limpeza e desobstrução do troço em questão. Esta poderá ser feita manualmente, ou com recurso a meios mecânicos. Normalmente a limpeza manual é usada quando não existem acessos para a viatura limpa-colectores ou quando há um único elemento a obstruir o colector, sendo fácil retirá-lo manualmente.

57 As técnicas usadas pelas equipas na limpeza e desobstrução com recurso a meios mecânicos consistem na lavagem com jacto de água sob pressão, na sucção (caso do equipamento limpa-fossas), ou por combinação destas duas técnicas, dependendo da viatura de limpeza que está a ser usada. A limpeza usando jacto/pressão de água requer o tamponamento da caixa de visita a jusante em relação ao troço em que a mesma é feita, sendo os sedimentos retirados na caixa de visita a jusante. A limpeza combinada de colectores consiste na limpeza dos colectores com jacto de água sob pressão efectuada no sentido contrário ao escoamento. Os sedimentos, encaminhados para montante são retirados depois por sucção.

58 A viatura tem dois compartimentos/reservatórios : um fornece água para limpeza (é abastecido de água em pontos de recolha - bocas de incêndio) e o outro recebe os sedimentos (que despeja em local apropriado - como o interceptor do Sistema Multimunicipal de Saneamento da Costa do Estoril - SANEST, localizado na Guia).

Uma síntese das tarefas e dos perigos associados às actividades de inspecção e desobstrução/limpeza na DSO são apresentados nas tabelas A1, A2 e A3, em anexo. A desobstrução e a limpeza podem ser realizadas em colectores e em fossas sépticas, estas últimas localizadas em áreas habitacionais dos munícipes dos dois concelhos.

Os colectores visitáveis apresentam também, pelas suas características físicas, riscos para os operadores. Como foi possível verificar no terreno de operações, as caixas de visita às quais o pessoal da exploração e manutenção pode ter acesso, poderão ter profundidade de $2,50 \mathrm{~m}$ ou superior e dispõem de superfícies sujas e húmidas o que poderá acarretar riscos, nomeadamente de escorregamento, queda em desnível ou queda em altura, queda ao mesmo nível e queda de objectos.

61 Caso haja necessidade de descer às caixas, tal procedimento deverá ser apoiado em medidas de segurança, tal como a utilização de guincho mecânico, cabo de linha de vida e arnês (equipamentos de segurança) para prevenção daqueles riscos.

62 São exemplos de locais de maior risco onde se processam os trabalhos no sector da limpeza e manutenção da rede de saneamento :

- Os colectores próximos de condutas de distribuição de gás ou tanques subterrâneos de combustível ;

- Os colectores com pouca inclinação (provável deposição de sólidos sujeitos a decomposição) ; 
- Os colectores (mais antigos) com câmaras/caixas muito afastadas (mais de noventa metros) especialmente se as ligações domiciliárias são munidas de sifão ;

- Os colectores com câmaras de profundidade superior a três metros ;

- Qualquer tanque ou câmara que possua tampa estanque, qualquer que seja a profundidade ;

- As fossas sépticas (com elevada formação de gases com efluentes de aspecto e cheiro desagradáveis e elevado grau de germes patogénicos).

Todas estas situações poderão constituir situações perigosas que, não sendo controladas e implementadas as devidas medidas de prevenção, poderão resultar em graves riscos para os trabalhadores e terceiros. São estas algumas das situações inerentes aos trabalhos observados e que importa ter presente na prossecução de uma aç̧ão de formação sobre a adopção de boas práticas.

\subsection{Pré-diagnóstico da situação de trabalho}

0 conhecimento das actividades desenvolvidas e as informações relativas aos acidentes de trabalho neste sector permitiram identificar os temas a abordar na formação :

- Actividades em espaços confinados - estes trabalhos são uma constante na profissão de varejador e apresentam características específicas que podem causar danos irreparáveis. Os acidentes podem ser evitados se o trabalhador estiver devidamente informado sobre os perigos associados à sua actividade de trabalho e as medidas preventivas a adoptar (Veiga, 2008) e se forem fornecidos os meios de protecção individual adequados.

- Posturas e movimentação manual de cargas durante a actividade de trabalho - o trabalho dos varejadores é maioritariamente feito junto ao solo envolvendo a manipulação de equipamentos pesados e sob pressão (mangueiras). Dos 4 acidentes de trabalho ocorridos na categoria profissional de varejadores no ano de 2007, todos foram devido à movimentação manual de cargas e à adopção de posturas desfavoráveis do ponto de vista biomecânico originando lesões a nível lombar.

\section{O processo formativo}

65 A gestão da formação privilegiou o recurso a métodos participativos, promovendo o debate e a construção de ideias, em estreita relação com a realidade de trabalho. Para este efeito, o formador teve um papel fundamental na condução da formação, moderando e estimulando a reflexão e a discussão do grupo. Sempre que necessário foram introduzidas explicações, dados e informações essenciais à compreensão pelos operadores das matérias em análise.

O estudo de caso foi a estratégia central no desenvolvimento das actividades formativas. A abordagem dos temas principais deste processo formativo desenvolveu-se recorrendo à exposição clara das problemáticas, com a identificação e reflexão em torno de cenários-problema e à visita ao local de trabalho onde foi possível a autoanálise apoiada. A cada tema dedicou-se três sessões de formação, distribuídas da seguinte maneira : duas sessões (reflexivas) em sala e uma sessão no local de trabalho (auto-análise do trabalho).

67 Aquando da realização do primeiro tema, " espaços confinados ", pareceu-nos ser mais benéfico para os operadores a alteração da ordem das sessões. Assim, procedemos ao 
ajustamento das sessões no tema “ posturas e movimentação manual de cargas » com a realização de uma sessão em sala antes da sessão de auto-análise do trabalho.

Outra técnica utilizada na aplicação do processo formativo, apresentando vantagem na análise reflexiva pelos operadores da sua actividade de trabalho, foi a exibição de filmagens obtidas no decurso da análise ergonómica do trabalho, realizada na primeira etapa. Durante a observação dos vídeos os operadores comentavam as acções sendo estes revistos sempre que a sua relevância o exigia (risco e/ou complexidade associada, opiniões divergentes, etc.).

Esta metodologia designada na literatura como " reflexão assistida " pode desenvolverse em " auto-confrontação » ou em " alo-confrontação ", conforme, respectivamente, a actividade reflexiva do sujeito se dirige à sua própria actividade de trabalho ou à de um sujeito seu par. A reflexão assistida pode ainda desenvolver-se em regime de “ confrontação colectiva " - foi o nosso caso - sendo a actividade reflexiva do grupo centrada na actividade de trabalho de um ou mais dos seus elementos. (Mhamdi, 1998 ; Mollo \& Falzon, 2004). Assim, os operadores tornam-se analistas das suas próprias actividades e das actividades dos seus pares, sendo debatidas situações-problema que se levantam durante as tarefas. A análise e a reflexão de procedimentos conduzem os operadores a exteriorizar os seus conhecimentos, implicando a descoberta de novos saberes (Mollo \& Falzon, 2004).

\subsection{Descrição sumária do conteúdo das sessões de formação}

\section{Sessão 1 : Sessão introdutória em grupo.}

Esta sessão começou pela apresentação dos objectivos do projecto, face às características específicas do trabalho realizado no saneamento, com o intuito de se motivar os operadores para a problemática da segurança no local de trabalho. Foram apresentadas notícias de acidentes ocorridos em Portugal em redes saneamento, solicitando comentários relativos essas ocorrências. Seguidamente, foram explicados os principais riscos associados à actividade no saneamento, os quais dependem sobretudo da natureza das infra-estruturas e da natureza das águas residuais. Foi ainda pedido, que enumerassem as medidas de segurança que normalmente são adoptadas e aquelas que deviam ser adoptas. Foram apresentadas fotografias do seu trabalho, solicitando a identificação das medidas de segurança presentes e ausentes nas imagens. Para concluir foram apresentadas as medidas de controlo de risco, os principais equipamentos de proteç̧ão individual e o respectivo nível de protecção para a actividade do saneamento.

\section{Sessão 2 : Auto-análise apoiada durante o trabalho : "espaços confinados ".}

71 Após a motivação para a problemática da segurança no local de trabalho, os operadores aplicaram os conhecimentos adquiridos na sessão anterior no seu próprio contexto profissional. Pretendeu-se com esta sessão, explicitar e enquadrar os conhecimentos gerais nas actividades profissionais quotidianas. Deste modo, foi-lhes pedido para enquanto trabalhavam, verbalizarem todas as suas decisões e gestos, para que estes aspectos se tornem conscientes.

Esta sessão teve a duração de uma manhã de trabalho e foram objecto de auto-análise duas actividades de trabalho planeadas para o momento. A primeira situação analisada, 
considerada por eles de "rotina", na medida em que acontece em muitos pontos do concelho, foi a retirada de raízes de árvores de uma caixa. Este trabalho é realizado com uma pá de caleira para auxiliar a retirada das raízes e diminuir a entrada nas caixas de visita. Ao longo do decorrer do trabalho foram questionados quanto ao tipo de riscos que encontram e aos acidentes de trabalho que já aconteceram e foi-lhes pedido que verbalizassem todas as acções realizadas. O segundo trabalho foi a limpeza de uma caixa com o apoio da viatura. Este trabalho foi realizado numa via pública que apresentava alguns constrangimentos, em concreto, largura reduzida dificultando a paragem da viatura e elevado fluxo de trânsito. A propósito das características desta intervenção foi abordado, no local, o assunto da sinalização rodoviária, tendo sido explicado pelos operadores que quando é uma intervenção demorada é usual o contacto com a Policia Municipal e o seu acompanhamento nos trabalhos. Foram ainda confrontados com o não cumprimento da sinalização de segurança fixada na viatura que determina a obrigatoriedade da utilização de equipamentos de proteç̧ão individual.

\section{Sessão 3 e 4 : Discussão em grupo.}

Dedicou-se esta sessão à apresentação teórica e discussão colectiva do tema " espaços confinados ", aferindo-se o grau de conhecimento dos operadores sobre esta matéria.

Esta sessão iniciou-se com a revisão da sessão anterior, em situação de trabalho, onde puderam, mais uma vez, verbalizar e reflectir sobre as actividades realizadas. Foi utilizado como material de formação um filme da sua própria actividade de trabalho, relativo à limpeza e desobstrução de um colector sem o apoio da viatura de limpeza, demonstrando a descida a um colector. Durante o visionamento do filme, os operadores foram verbalizando as suas acções e gestos, referindo as medidas de segurança que ficaram omissas no desenrolar do trabalho e identificadando e discutindo as características dos espaços confinados. No decorrer da sessão os operadores relataram vivências pessoais e colectivas, em cada risco identificado. Foi ainda debatido o problema da claustrofobia. As reflexões dos operadores revelaram os saber-fazer de prudência (Cru, 1987) inseridos no seio deste grupo e que constituem regras de trabalho não-escritas nas actividades de limpeza e desobstrução de colectores sem apoio da viatura. As regras referidas são relativas à protecção do operador que desce ao interior das caixas de visita (vd. ponto 5 - procedimentos).

\section{Sessão 5 : Discussão em grupo.}

A sessão 5 teve como tema " posturas e o levantamento e movimentação manual de cargas ». Recriando em sala diferentes modalidades de levantamento manual de uma carga foi possível demonstrar os riscos associados a diferentes procedimentos. A partir da realização deste exercício foi possível explicar a origem de algumas lesões, nomeadamente da hérnia discal, de entorses e luxações. Foram também analisados os parâmetros dos quais dependem os valores limites de uma carga. A terminar a sessão foram apresentadas fotografias de operadores em actividade de trabalho, incentivando o debate sobre as posturas adoptadas. 


\section{Sessão 6 : Auto-análise apoiada durante o trabalho : “ Postura no trabalho/ levantamento e movimentação manual de carga ".}

Esta sessão teve a duração de uma manhã de trabalho, 4 horas, tendo sido objecto de auto-análise duas actividades planeadas para a ocasião de desobstrução de caixas de águas pluviais. Ao longo do decorrer dos trabalhos foi-lhes pedido que verbalizassem todas as acções realizadas, as dificuldades encontradas, bem como as estratégias para as resolver, como por exemplo, a necessidade de “puxar a mangueira» quando se encontra presa. Foram igualmente questionados sobre os procedimentos de trabalho que podem ser realizados noutras condições, como por exemplo, quando não é possível a utilização da mangueira da viatura para desobstruir e se recorre à pá de caleira.

\section{Sessão 7 : Discussão em grupo.}

77 Na sessão 7 foram discutidos detalhes importantes das posturas adoptadas durante o trabalho e do levantamento e movimentação manual de cargas. Foram utilizados como material de formação dois filmes realizados na primeira etapa deste projecto. Num dos filmes podíamos ver a actividade de desobstrução de colector com auxílio da mangueira e no outro a actividade de despejo da fossa séptica. Durante o visionamento dos filmes, os operadores foram explicando/comentando as suas acções e gestos e foram identificando as posturas incorrectas adoptadas durante o trabalho. Esta sessão terminou com a síntese dos princípios de movimentação manual de cargas.

\section{Sessão 8 - Balanço da formação}

Nesta sessão pretendeu-se que todos os participantes tivessem oportunidade de fazer o balanço de todo o processo formativo. Apesar do conhecimento prático que o grupo tinha, foi unânime a opinião sobre o benefício destas sessões no sentido de uma maior consciencialização da realidade de trabalho de cada um. Da discussão gerada sobre a formação foi solicitado que concretizassem propostas de melhoria das condições de trabalho, a apresentar posteriormente aos seus superiores hierárquicos. Assim surgiram propostas referentes aos recursos humanos, recursos materiais, procedimentos de trabalho e formação.

\section{Sessão 9 - Apresentação do balanço realizado e debate com os responsáveis da organização}

Foram apresentadas e debatidas as conclusões saídas da sessão anterior, contando com a presença de todos os operadores que participaram no processo formativo e de superiores hierárquicos: Administrador, Directora-Delegada, Director de Departamento de Água e Saneamento e Chefe de Divisão do Saneamento de Oeiras.

A análise das sessões até então realizadas e as propostas de melhoria das condições de trabalho feitas pelos operadores orientaram a organização desta sessão. Introduzimos os temas que foram objecto de análise e discussão - os recursos humanos e materiais, os procedimentos de trabalho e a formação - através da apresentação de frases-chave proferidas pelos operadores ao longo do processo formativo. A partir da apresentação das frases originou-se um debate de ideias entre os diferentes actores, tendo a hierarquia superior demonstrado necessidade em conhecer melhor as práticas de trabalho destes operadores, para poder compreender as propostas de melhoria das 
condições de trabalho. No final desta sessão foi assumido pela Administração, perante os operadores, implementar todas as medidas propostas, procurando a contrapartida de os operadores assumirem a melhoria das práticas de segurança nos procedimentos de trabalho.

\section{Procedimentos de trabalho: um tema central no debate colectivo}

81 A transcrição dos registos vídeo das sessões foi analisada segundo dois eixos, o tema e o modo de discurso.

82 A figura 4 mostra a distribuição dos temas abordados na totalidade das 9 sessões e a figura 5 a distribuição dos temas em cada uma das sessões.

Figura 4 - Temas abordados (em frequência relativa) (RH-recursos humanos, $\mathrm{RM}$ - recursos materiais, PT - procedimentos de trabalho, Form - Formação).

\section{Form $\quad \mathrm{RH}$}

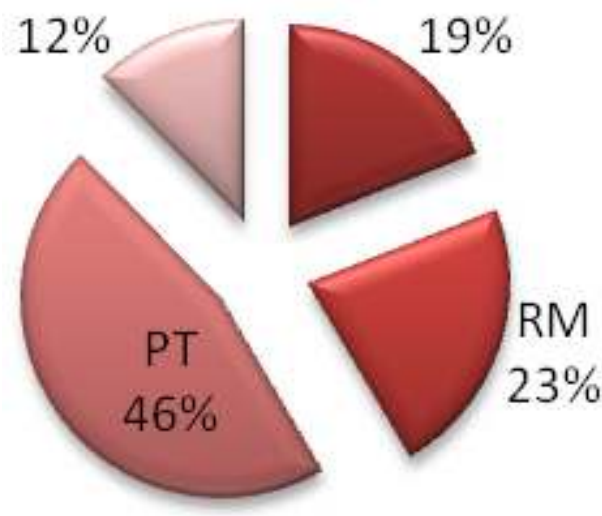

$\mathrm{RH} \square \mathrm{RM} \square \mathrm{PT} \square$ Form
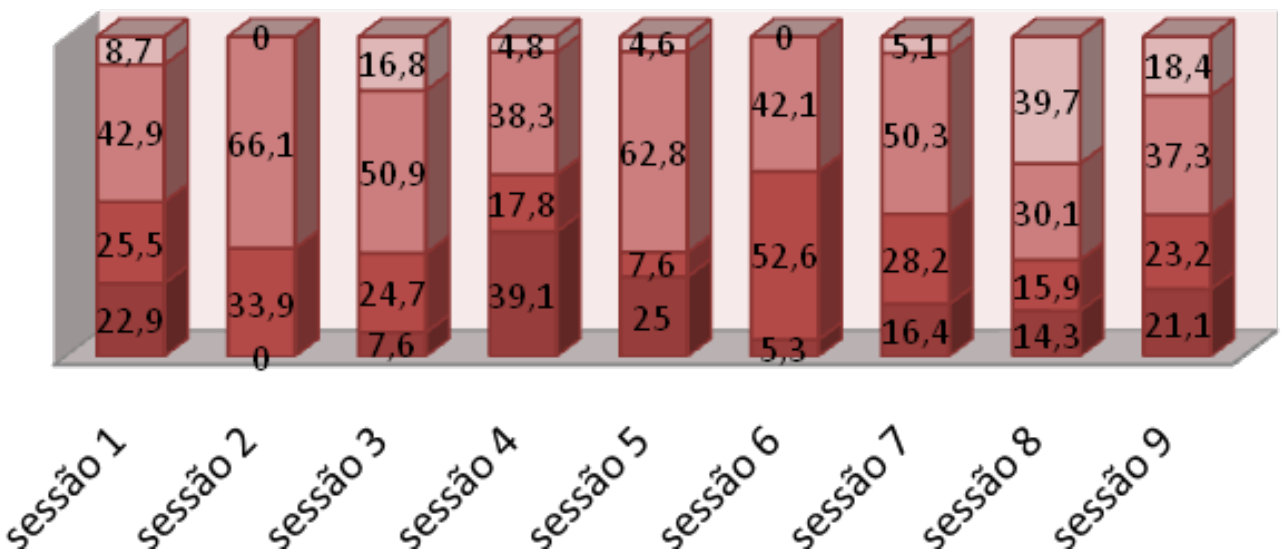
Figura 5 - Distribuição dos temas por sessão (em frequência relativa) (RH-recursos humanos, RMrecursos materiais, PT-procedimentos de trabalho, Form-formação)

São de realçar os seguintes aspectos :

- tema mais presente no diálogo dos operadores é "procedimentos de trabalho", seguido de "recursos materiais";

- Nas sessões 2 e 6 , as sessões que decorram no local de trabalho, foram notórios os temas sobre "procedimentos de trabalho" e "recursos materiais", constituindo 66,1\% e 33,9\%, respectivamente, na sessão 2, e 42,1 \% e 52,6 \%, respectivamente, na sessão 6 ;

- A temática da "formação" esteve mais presente nas sessões finais de balanço do processo formativo ; ao longo das restantes sessões, a formação foi sendo pontualmente reflectida na sua actividade profissional ;

- Na sessão 4 verifica-se um aumento do tema " recursos humanos ", visto ter sido a sessão em que foram relatadas vivências pessoais e colectivas e a demonstração dos saber-fazer de prudência ;

- Nas sessões 8 e 9 observa-se uma distribuição mais uniforme dos temas abordados. Esta situação prende-se com o facto de todos os temas abordados terem sido re-explorados na elaboração e debate das propostas de melhoria.

84 A figura 6 exibe a distribuição dos modos de discursos utilizados pelos operadores nos temas abordados durante todo o processo formativo.

Figura 6 - Distribuição dos modos de discursos utilizados por tema : (a) recursos humanos ; (b) recursos materiais ; (c) procedimentos de trabalho ; (d) formação (em frequência relativa).

A partir da análise da figura 6 e do conteúdo do protocolo verbal chegou-se às seguintes constatações ao nível das diferentes temáticas abordadas.

\section{Recursos Humanos}

A actividade desenvolvida pelo sector de saneamento apresenta características que, na opinião dos operadores, a distingue das demais actividades de trabalho e origina uma representação social de "trabalho sujo" (cit. protocolo verbal) e sujeito a "odores desagradáveis" (id.). o pouco reconhecimento social gerado por estas características dificulta o recrutamento para este serviço e desencadeia no seio do próprio colectivo de operadores necessidades de afirmação da identidade e sentimentos de diferença face ao sector das Águas.

87 A falta de recursos humanos para o volume de trabalho na área de actuação obriga a que as intervenções sejam realizadas no mínimo tempo possível, potenciando a adopção de práticas incorrectas apesar de afirmarem compreenderem o risco a que se encontram expostos: "Há algumas condições, mas como há pouco pessoal temos que fazer o trabalho rápido, desenrascar isto, e isso pode provocar acidentes. Temos consciência disso"(id.). Apesar deste constrangimento, referem que a tomada de consciência perante os riscos tem aumentado nos últimos anos. Contudo, não obstante a falta de recursos humanos e materiais, consideram ter um grande sentimento de responsabilidade na concretização do seu trabalho.

O tema " recursos humanos" foi muitas vezes associado às dificuldades sentidas na resolução dos trabalhos, sendo frequente o enunciado de conselhos e opiniões relacionados com a carência de recursos humanos (modo axiológico), desencadeados pela descrição e explicação de factos e acontecimentos (modo constantivo e 
explicativo). Visto ser uma dificuldade sentida pelo grupo, observa-se a associação do modo imperativo a este tema, "os responsáveis têm que tomar uma atitude ou colocar pessoal novo"(id.).

\section{Recursos Materiais}

Apesar de ser apontada pouca eficiência e adequabilidade a alguns equipamentos de protecção individual (EPI's), a outros associam-se mudanças positivas, como por exemplo, a substituição dos fatos oleados por fatos descartáveis para a realização de actividades nas caixas de visita. Muitos dos EPI's não são utilizados devido à convicção de que não são verdadeiramente protectores, à falta espaço nas viaturas para os transportar, às características dimensionais das caixas de visita e à ausência de adopção rotineira de procedimentos de segurança. A falta de alguns recursos materiais induz à improvisação de outros - "a espátula foi inventada por nós para cortar as raízes" (id.) com o intuito de ajudar na execução de tarefas e de reduzir a necessidade de entrada nas caixas de visita, para a realização de determinados trabalhos. Este último objectivo alicerça-se no sentimento de incapacidade para responder adequadamente à imprevisibilidade de condições no interior das caixas.

Outra problemática referente aos "recursos materiais ", diz respeito às mangueiras, objecto que está na origem de alguns acidentes de trabalho : "não se consegue prever. Pode estar roçada e durar uma vida, como pode estar nova e rebentar."

Deste modo salienta-se a descrição dos recursos materiais existentes e de que forma improvisam (modo constantivo e explicativo), de acordo com as suas necessidades (modo axiológico), conseguindo identificar os recursos que são precisos adquirir (modo imperativo) : "agora falta o material para podermos fazer melhor"(id.)

\section{Procedimentos de Trabalho}

No tema "procedimentos de trabalho" foram descritas: (i) as actividades diárias actuais e passadas (ii) os acidentes de trabalho que ocorreram no próprio grupo ; (iii) a utilização (ou não) dos equipamentos de protecção individual; e (iv) os métodos de trabalho que estão presentes no seio daquele grupo de operadores.

Sempre que as intervenções resultam de uma planificação prévia, foi afirmado ser prática corrente organizar os recursos materiais necessários e disponíveis. Mas, quando as intervenções assumem um carácter de urgência, devido à extensão da área de actuação, à falta de recursos humanos, a imperativos de conclusão do trabalho, comprometem seriamente a adopção de procedimentos de segurança. Apesar disso, foram identificados "saber-fazer de prudência " não formalizados constituindo regras de trabalho "formalizadas» do ponto de vista do colectivo, por exemplo procedimentos de protecção dos elementos do colectivo que descem ao interior das caixas de visita : (i) o operador que desce a uma caixa de visita nunca é o com mais idade : "não é um homem com 50 anos que lá vai"(id.), nem o mais robusto, de modo a que, em situação de emergência, possam auxiliar a sua subida e retirada do interior da caixa ; (ii) acompanhamento, por dois ou três operadores na superfície, das operações realizadas no interior da caixa: "estão sempre dois homens ao pé da caixa, nunca ninguém vai lá sozinho" (id.) ; (iii) manter permanentemente o diálogo com o operador que se encontra dentro da caixa, com o intuito de retirar daí informações sobre o seu 
estado de lucidez e auto-controlo: "depois o procedimento que temos é manter a ligação com ele, conversar com ele” (id.).

Como se verifica na figura 5 , referente à distribuição dos temas por cada sessão, o tema “ procedimentos de trabalho » é o que apresenta maior percentagem em cada sessão. 0 modo constantivo revela-se o modo mais utilizado no discurso quando o tema é "procedimentos de trabalho", sendo logo a seguir o modo axiológico. Verificou-se também o recurso ao modo explicativo para mostrar as razões da prática de alguns procedimentos. Deste modo, verificamos que é o tema onde se observa maior necessidade de debate de ideias.

\section{Formação}

Outro aspecto evidenciado foi a falta de formação profissional e técnica incitando a práticas de ensino no posto dos mais antigos e experientes aos mais novos. Estas práticas potenciam a transmissão de procedimentos largamente enraizados, mas nem sempre correctos : "Há falta de formação profissional e o que aprendemos é uns com os outros e depois aprende-se os maus vícios.”(id.).

Consideram ter conhecimentos suficientes, decorrentes da sua experiência : "ninguém os ensinou como se utilizava as verguinhas, eles vão aprendendo é com a experiência de vida que vão tendo"(id.), que lhes permite identificar os riscos a que estão expostos. Mas, devido aos fortes constrangimentos resultantes das condições de exercício do próprio trabalho, correm riscos e têm acidentes. Neste sentido, os modos de discurso mais utilizados são o modo constantivo e o modo axiológico.

De modo geral, neste tema verifica-se que o grupo de operadores indicam quais são as carências e que métodos de formação devem ser considerados, como é o caso de formação técnica dos equipamentos adquiridos, para isso recorrem ao modo imperativo : "tem que vir alguém explicar, isto funciona assim, nunca façam isso, pode ocorrer o risco de acontecer isto, isto é que é o procedimento correcto"(id.)

\section{Qual o impacto do processo formativo no quotidiano de trabalho?}

\subsection{Regresso ao terreno}

Após sete meses do término do processo formativo, procedeu-se à reavaliação das características da situação de trabalho - sessão 10 -, no sentido de verificar a implementação de alguns compromissos assumidos, na sessão de formação 9, pelos responsáveis da Organização, nomeadamente, admitir novos operadores, adquirir melhores equipamentos de protecção individual, adquirir uma viatura, fornecer formação técnica sempre que sejam adquiridos materiais e equipamentos. Promoveu-se também um debate sobre a transformação das condições de trabalho entretanto ocorridas.

\section{Sessão 10 : Reavaliação das características da situação de trabalho}

Interpelámos as unidades orgânicas competentes para a implementação destas medidas, para analisar o nível de execução de cada compromisso. No que diz respeito à 
admissão de novos operadores, fomos informados, na altura, que o procedimento concursal estava a decorrer. Após a divulgação da abertura de vagas e do período das candidaturas, a DGRH encontrava-se na fase de selecção dos concorrentes. $O$ processo ficou concluído no mês de Julho de 2009. O Sector de Segurança e Saúde Ocupacional (SSSO) da DGRH realizou o diagnóstico das necessidades nos diferentes serviços e abriu o procedimento de adjudicação dos equipamentos de protecção individual adequados às actividades desenvolvidas. Os equipamentos de protecção individual foram distribuídos pelos operadores em Janeiro de 2009 e na sequência foi dada formação técnica adequada. Auscultada a chefe da DSO sobre o processo de aquisição de mais uma viatura, a mesma informou-nos da existência de uma carrinha de apoio, na Divisão de oficinas e Transportes, que quando necessário pode ser requisitada e colocada ao serviço da DSO.

100 Verificámos, assim, que a Organização assumiu a implementação dos compromissos assumidos perante os operadores.

Por sua vez, os operadores assumiram o compromisso de "a segurança acima de tudo, mas criem condições de trabalho. Se criarem condições de trabalho não há falhas na segurança, porque não há facilitismos." (cit. protocolo verbal)

Como referimos foram realizados acompanhamentos às intervenções desenvolvidas no terreno, com o objectivo de proceder novamente a uma análise da actividade e assim verificar as transformações ocorridas no seio deste grupo de operadores. Constatámos nas visitas ao terreno a utilização de equipamentos de proteç̧ão individual, nomeadamente, o colete de alta visibilidade e luvas mais adequadas aos riscos biológicos, estando presente com cada um dos operadores, para a eventual utilização, a máscara, o capacete, a viseira, os protectores auditivos e os óculos de protecção. No que diz respeito aos princípios da movimentação manual de cargas, verificou-se a preocupação dos operadores em adoptar medidas de segurança transmitidas. Da mesma forma observou-se o cuidado em assegurar uma postura correcta durante o trabalho de desobstrução de colectores com o auxílio da mangueira. Ainda que possamos assumir alguma influência gerada pela presença do formador no terreno, relativamente à adopção dessas práticas, é um facto que até Julho de 2010 não houve qualquer registo de acidente de trabalho do foro músculo-esquelético (vd. ponto 6.2)

Deparámo-nos, no entanto, com uma deficiente sinalização das vias públicas durante realização de trabalhos de inspecção periódica. 0 mesmo já não aconteceu nos trabalhos de limpeza e desobstrução, onde a sinalização utilizada era adequada.

104 Seguidamente à análise das transformações ocorridas no local de trabalho, foi elaborada uma sessão final (sessão 11) para a qual compilámos toda a informação referente à execução dos compromissos assumidos por ambas as partes.

\section{Sessão 11 - Discussão das propostas implementadas com os operadores}

Nesta sessão pretendeu-se demonstrar e debater com os operadores a execução dos compromissos assumidos pela Organização e pela DSO, mas também os assumidos pelo próprio grupo. Citando o encarregado há o cumprimento dos compromissos "quase na totalidade. A consciencialização do pessoal. Eu penso que eles adquiriram outro tipo de consciência, usam o equipamento normalmente." (cit. protocolo verbal).

106 Foram utilizados filmes da actividade de trabalho, antes e após da formação. Ambos os filmes demonstravam a desobstrução de um colector com o apoio da viatura de 
limpeza, tendo sido pedido que comentassem e identificassem as transformações ocorridas entre os dois momentos. Foi discutida a prática de sinalização deficiente das vias públicas durante os trabalhos, por eles designados, de curta duração, tendo sido, novamente, alertados para a importância de uma sinalização adequada e incitados à sua utilização em todos os trabalhos na via pública. No entanto, em relação à constatação da deficiente sinalização, emergiu mais um saber-fazer de prudência implementado no seio destes operadores: "Nós normalmente temos a preocupação, há alguns mais relaxados que outros. Mas naquele dia houve a preocupação de colocar a carrinha à frente da caixa, quer dizer atrás do que nós ia-mos fazer, 4 piscas a trabalhar da carrinha e depois foi posto pinos até fechar aquela via da rotunda (...)" (cit. protocolo verbal).

Em toda a sessão foi referida, apenas, uma única anotação sobre a Organização, relativa ao facto da viatura solicitada não ser uma viatura de apoio, mas uma viatura de limpeza e desobstrução de redes, de modo a permitir a organização efectiva do trabalho e o planeamento das actividades. Esta necessidade vai ser reforçada pela chefia directa à Administração para cabimentação num próximo orçamento.

A redução das actividades feitas contra-tempo devido à escassez de recursos (materiais e humanos) será um contributo inegável para a segurança. A gestão da segurança passa pelo reforço das equipas, pelo apetrechamento material, em sintonia com uma adequada organização e planeamento das actividades.

\subsection{Análise de Sinistralidade}

Para a análise da sinistralidade comparámos os dados de 2007 e 2008 fornecidos pelo SSSO.

110 Como referimos anteriormente (vd. figura 1.) os varejadores constituíam em 2007 o grupo profissional com maior registo de acidentes de trabalho nos SMAS de Oeiras e Amadora (4 ocorrências). Em 2008, o número total de acidentes de trabalho no mesmo sector de actividade nos SMAS de Oeiras e Amadora foi de 2 ocorrências.

111 Considerando o período de 6 meses desde a formação e a reavaliação da situação, não se registaram acidentes de trabalho no grupo de operadores do sector de saneamento que estiveram presentes no processo de formação. De Maio de 2009 até Junho de 2010 não se verificou ocorrências neste sector de actividade.

\section{Considerações finais}

A partir da análise do contexto profissional do sector do saneamento desenvolveu-se e implementou-se um projecto formativo que contribuiu para a sensibilização e a interiorização de comportamentos de segurança e para a transformação das condições de trabalho tendo em vista a prevenção de riscos profissionais dos varejadores.

113 Os resultados apresentados demonstram a pertinência e o potencial que as abordagens formativas participativas podem ter, constituindo uma verdadeira alternativa a modelos de promoção da segurança "tradicionais" (do tipo exclusivamente expositivo). Para além disto, a tomada em consideração das características específicas do grupo, em concreto, a idade e o nível de escolaridade, na organização e condução pedagógica das sessões, constituiu um elemento distintivo deste processo formativo. 
114 Para além da marca, indiscutível, deixada por este projecto no terreno, foi possível contaminar diferentes categorias de trabalhadores (operadores e decisores) com um outro olhar e capacidade de acção na promoção da segurança. Demonstrou-se também a mais valia de concebermos uma formação "situada" e "oportuna".

115 O papel de mediação assumido pelo formador revelou-se de enorme importância. Orientando-se ora para o desenvolvimento individual, intrinsecamente ligado à explicitação e formalização do saber, ora para o desenvolvimento colectivo, criando dinâmicas de confrontação de experiências e de saberes e de enriquecimento mútuo, ora para o reconhecimento social afim de dar significado na empresa àquela experiência.

116 Para o formador foi possível observar procedimentos de segurança não-escritos, enraizados nas práticas de trabalho deste grupo de operadores, os saber-fazer de prudência (Cru, 1987). Constituem, como refere o autor, "procedimentos espontâneos de luta contra os acidentes e de uma maneira geral contra o sofrimento (esforço inútil, a fadiga, etc.) são em parte inconscientes, retidos num saber-fazer colectivo, a arte do ofício, as tradições, os hábitos" (p. 172). Apesar do seu carácter informal, estas práticas convergem para os objectivos preventivos do formador - também técnico de segurança, higiene e saúde no trabalho - inserido nesta Organização, e revelam-lhe uma outra dimensão, até então pouco visível, das "longas elaborações do ofício" (op. cit., p. 172) desencadeadas pelos constrangimentos quotidianos do trabalho no saneamento. A explicitação destes saberes pelos trabalhadores, o reconhecimento da sua relevância e tradução em procedimento de segurança pelos responsáveis e a sua posterior difusão no interior da empresa constitui um inegável contributo no sentido da promoção da saúde e da segurança.

117 Assim, o projecto formativo desenvolvido não é inócuo para os operadores, para os responsáveis na Organização, para a própria Organização, mas também para o próprio formador que, à saída, adquiriu outra representação sobre o trabalho no saneamento e outra capacidade de intervenção no domínio da segurança, higiene e saúde no trabalho.

Temos consciência da necessidade de alimentar a dinâmica que foi criada com este projecto, neste grupo de operadores, porque como os próprios afirmaram "nós vamos indo aos poucos, o vício já era tão grande...”(cit. protocolo verbal). A monitorização periódica da actividade de trabalho, associada ao reforço da formação sempre que se justifique, constitui uma das vias que permite dar continuidade à melhoria contínua dos procedimentos de segurança, no grupo de operadores participantes e à promoção da segurança, higiene e saúde no trabalho nesta Organização.

\begin{tabular}{|l|l|l|}
\hline Tarefas & Perigos & Riscos \\
\hline \multirow{2}{*}{ 1-Sinalizar a via } & $\begin{array}{l}\text { Tráfego intenso } ; \\
\text {. Locais de visibilidade reduzida ; }\end{array}$ & . Atropelamento ; \\
\hline
\end{tabular}




\begin{tabular}{|c|c|c|}
\hline $\begin{array}{l}\text { 2-Retirar tampa e abrir a } \\
\text { caixa }\end{array}$ & $\begin{array}{l}\text {. Peso da tampa; } \\
\text {. Objectos em altura; } \\
\text {. Partículas sólidas e águas residuais ; } \\
\text {. Gases/vapores tóxicos; } \\
\text {. Desnível da caixa; }\end{array}$ & $\begin{array}{l}\text { Postura incorrecta/Lesões } \\
\text { músculo-esqueléticas; } \\
\text {. Queda de objectos; } \\
\text {. Escorregamento; } \\
\text {. Queda em altura; } \\
\text {. Projecção de partículas } \\
\text { sólidas e águas residuais; } \\
\text {. Inalação de gases/vapores } \\
\text { tóxicos; }\end{array}$ \\
\hline $\begin{array}{l}\text { 3-Descer ao interior do } \\
\text { colector (espaço confinado) }\end{array}$ & $\begin{array}{l}\text {. Gases/vapores tóxicos; } \\
\text {. Carência de oxigénio; } \\
\text {. Roedores e insectos; } \\
\text {. Agentes patogénicos; } \\
\text {. Desnível da caixa; }\end{array}$ & $\begin{array}{l}\text {. Escorregamento; } \\
\text {. Queda em altura; } \\
\text {. Projecção de partículas } \\
\text { sólidas e águas residuais; } \\
\text {. Inalação de gases/vapores } \\
\text { tóxicos; } \\
\text {. Asfixia; } \\
\text { Entrada de agentes } \\
\text { patogénicos no organismo; }\end{array}$ \\
\hline $\begin{array}{l}\text { 4-Desobstruir/limpar } \\
\text { dentro do colector (espaço } \\
\text { confinado) }\end{array}$ & $\begin{array}{l}\text {. Objectos em altura; } \\
\text {. Ambiente sujo e húmido; } \\
\text {. Gases/vapores tóxicos; } \\
\text {. Carência de oxigénio; } \\
\text {. Roedores e insectos; } \\
\text {. Agentes patogénicos; } \\
\text {. Ruptura de dispositivo de retenção de } \\
\text { caudal/controlo de escoamento de } \\
\text { águas residuais; }\end{array}$ & $\begin{array}{l}\text {. Postura incorrecta/Lesões } \\
\text { músculo-esqueléticas; } \\
\text {. Queda de objectos; } \\
\text {. Afogamento; } \\
\text {. Inalação de gases/vapores } \\
\text { tóxicos; } \\
\text {. Asfixia; }\end{array}$ \\
\hline 5-Subir para o exterior & . Altura da caixa de visita ; & . Queda em altura ; \\
\hline 6-Recolocar a tampa & $\begin{array}{l}\text {. Objectos em altura } \\
\text {. Peso da tampa } \\
\text {. Desnível da caixa }\end{array}$ & $\begin{array}{l}\text {. Postura incorrecta/Lesões } \\
\text { músculo-esqueléticas; } \\
\text {. Queda de objectos; }\end{array}$ \\
\hline 7-Retirar a sinalização & $\begin{array}{l}\text { Tráfego intenso } \\
\text {. Locais de visibilidade reduzida. }\end{array}$ & . Atropelamento. \\
\hline
\end{tabular}




\section{BIBLIOGRAFIA}

Benchekroun, H.,Bourgeois, F.,Hubault, F. (2002). Comment aider l'encadrement de proximité à faire des arbitrages face à des situations à risques. Actes du XXXVII Congrès de la SELF "Les évolutions de la prescription". Aix-en-Provence, 25-27 Septembre, pp 376-384.

Bisseret, A., Sebillote, S., Falzon, P. (1999). Technique pratiques pour l'étude des activités expertes. Toulouse, Octares Editions, 69 - 84.

Bourrier, M. (1998). Le pouvoir sur les règles : la gestion des procédures de maintenance dans l'industrie nucléaire. Performances Humaines \& Techniques,(94), 30-36

Bourrier, M. (2001). La fiabilité est une question d'organisation. In M. Bourrier (Ed.), Organiser la fiabilité. Paris : L'Harmattan, pp. 9-38

Correia, M. (2002). Sistemas públicos de saneamento de águas residuais urbanas. Lisboa : IDICT.

Costa, C. (2010). Formação em Contexto Profissional. Análise da Importância da Formação Contextualizada no Desenvolvimento de Actos Seguros num Grupo de Operadores do Sector do Saneamento. Tese de Mestrado. Lisboa : FMHUTL.

Cru, D. (1987). Langue de Metier et Organisation du Travail. Revue de Médecine du Travail, 5, 171-178.

Decreto-Lei n. 330/93. Prescrições mínimas de segurança e saúde na movimentação manual de cargas. Diário da República n.ำ226, I série - A, de 25 de Setembro de 1993, 5391-5393.

Decreto-Lei n.․4 441/91. Regime jurídico do enquadramento da segurança, higiene e saúde no trabalho. Diário da República n.o 262, I série - A, de 14 de Novembro de 1991, 5826-5833.

Decreto-Regulamentar n.․ 33/88 de 12 Setembro. Sinalização de obras e obstáculos na via pública. Consultado em 23 de Março de 2008 em : http://www.epralima.pt/inforadapt/index.php/ inforadapt/content/view/full/1396

de Terssac, G. (2002). Travail et régulations sociales. In G. d. Terssac (Ed.), Le travail : une aventure collective. Toulouse : Editions Octares, pp. 79-90.

Divisão de Gestão de Recurosos Humanos (2008). Balanço social de 2007. SMAS de Oeiras e Amadora. Divisão de Gestão de Recurosos Humanos (2009). Balanço social de 2008. SMAS de Oeiras e Amadora. Girin, J., \& Grosjean, M. (Eds.). (1996). La transgression des règles au travail. Paris : L'harmattan. Lacomblez, M. Santos, M. e Vasconcelos, R. (1999). Da didáctica profissional à ergonomia e formação - A incontornável referência ao real. In. H. Lopes ; M. Lacomblez, R. Vasconcelos, L. Pires, M. Santos, T. Calapez. Aplicação de Metodologias de Formação para Adultos Pouco Escolarizados. Lisboa, Observatório do Emprego e Formação Profissional, Estudos e Análises, 15, 85-117.

Lacomblez, M., Teiger, C. (2007). Ergonomia, formações e transformações. In P. Falzon (ed) Ergonomia. São Paulo, Blucher, 587-601.

Lacomblez, M. ; Vasconcelos, R. (2009). Análise ergonómica da actividade, formação e transformação do trabalho : opções para um desenvolvimento durável. Laboreal, 5 (1), 53-60. http://laboreal.up.pt/revista/artigo.php?id=37t45nSU5471123592231593411

Massena, M. (2006). Potencialidades da análise ergonómica do trabalho na construção de uma prevenção integrada e participada. Lisboa, ISHST. 
Mhamdi, A. (1998). Les Activites de Reflexion Collective Assistée por Video : un outil pour la prevention. These de Doctorant. Paris, Conservatoire National des Arts et Métiers.

Mollo, V., e Falzon, P. (2004). Auto-and allo-confrontation as tools for reflective activities. Applied Ergonomics, 35, 531-540.

Paumès, D., Marquié, J.C. (1995). Travailleurs vieillissants, apprentissage et formation profissionnelle. In J.C. Marquiè, D. Paumés, S. Valkoff, Le travail au fil de l'âge. Toulouse, Editions Octores, coll. Travail, 391-410.

Portaria nº 762/2002, Regulamento de Segurança, Higiene e Saúde no Trabalho na exploração dos Sistemas Públicos de Distribuição de Água e de Drenagem de Águas Residuais. Diário da República n.. 149, I série - B, de 1 de Julho de 2002, 5123-5130 ;

Ré, A. (2006). Aprrendre des erreurs, apprendre du quotidien : deux approches actuelles pour une analyse collective de l'activité. Education Permanente, ํำ166, 49-57.

Resolução de Conselho de Ministros n.ำ59/2008, Estratégia Nacional para a Segurança e Saúde no Trabalho 2008-2012. Diário da República n.․ 64, I série, de 1 de Abril de 2008, 1984-1995 ;

Vasconcelos, R. ; Duarte, S., D. ; Moreira, V. (2010), Projecto Matriosca : Análise do trabalho, formação e acção

participativa para a prevenção de acidentes. Proceedings of International Symposium on Occupation Safety and Hygiene 11-12 Feb. Guimarães:Portuguese Society of Occupational Safety and Hygiene, 542-546.

Veiga, R.(2008) (coord). Segurança, higiene e saúde no trabalho. Um guia prático imprescindível para a sua actividade diária. Lisboa, Edições Verlag Dashofer.

Vergnaud, G. (2001). O desenvolvimento cognitivo do adulto. P. Carre, \& P. Caspar. Tratado das Ciências e das Técnicas de Formação. Porto Alegre, Instituto Piaget. 207-221.

\section{ANEXOS}

Tabela A1 - Desobstrução/limpeza de fossas sépticas

\begin{tabular}{|l|l|l|}
\hline Tarefas & Perigos & Riscos \\
\hline 1-Sinalizar a via & $\begin{array}{l}\text { Tráfego intenso } \\
\text { Locais de visibilidade } \\
\text { reduzida }\end{array}$ & . Atropelamento \\
\hline $\begin{array}{l}\text { 2-Retirar tampa e abertura da tampa } \\
\text { da caixa }\end{array}$ & $\begin{array}{l}\text {. Pajectos em altura } \\
\text { residuais } \\
\text {. Gases/vapores tóxicos } \\
\text {. Desnível da fossa } \\
\text {. Superfícies escorregadias }\end{array}$ & $\begin{array}{l}\text {. Postura incorrecta/Lesões músculo- } \\
\text { esqueléticas } \\
\text { - Queda de objectos } \\
\text { - Escorregamento } \\
\text {. Pueda em desnível } \\
\text { residuais }\end{array}$ \\
\hline
\end{tabular}




\begin{tabular}{|c|c|c|}
\hline $\begin{array}{l}\text { 3-Puxar mangueira de } \\
\text { sucção/aspiração }\end{array}$ & . Peso da mangueira & $\begin{array}{l}\text {. Postura incorrecta/Lesões músculo- } \\
\text { esqueléticas }\end{array}$ \\
\hline 4-Esvaziar a fossa séptica & $\begin{array}{l}\text { Superfícies sujas } \\
\text { escorregadias } \\
\text {. Mangueira sobre pressão } \\
\text {. Gases/vapores tóxicos } \\
\text {. Partículas sólidas e águas } \\
\text { residuais } \\
\text {. Agentes patogénicos } \\
\text {. Desnível da fossa }\end{array}$ & $\begin{array}{l}\text { Accionamento inadvertido de } \\
\text { máquinas e equipamentos } \\
\text {. Lesões músculo-esqueléticas } \\
\text {. Projecção da mangueira } \\
\text {. Projecção de partículas sólidas e águas } \\
\text { residuais } \\
\text {. Inalação de gases/vapores tóxicos } \\
\text {. Entrada de agentes patogénicos no } \\
\text { organismo } \\
\text {. Queda em desnível }\end{array}$ \\
\hline 5-Recolher a mangueira & $\begin{array}{l}\text {. Partículas sólidas e águas } \\
\text { residuais }\end{array}$ & $\begin{array}{l}\text {. Postura incorrecta/ Lesões músculo- } \\
\text { esqueléticas } \\
\text {. Projecção de partículas sólidas e águas } \\
\text { residuais }\end{array}$ \\
\hline 6-Recolocar a tampa & $\begin{array}{l}\text {. Objectos em altura } \\
\text {. Peso da tampa } \\
\text {. Desnível da fossa }\end{array}$ & $\begin{array}{l}\text {. Postura incorrecta/Lesões músculo- } \\
\text { esqueléticas; } \\
\text {. Escorregamento } \\
\text {. Queda em desnível } \\
\text {. Queda de objectos }\end{array}$ \\
\hline 7-Retirar a sinalização & $\begin{array}{l}\text { Tráfego intenso } \\
\text {. Locais de visibilidade } \\
\text { reduzida }\end{array}$ & . Atropelamento \\
\hline
\end{tabular}

Tabela A2 - Inspecção e desobstrução/limpeza de colectores com apoio da viatura

\begin{tabular}{|l|l|l|}
\hline Tarefas & Perigos & Riscos \\
\hline 1-Sinalizar a via & $\begin{array}{l}\text { Tráfego intenso } \\
\text {. Locais de visibilidade reduzida }\end{array}$ & . Atropelamento \\
\hline
\end{tabular}




\begin{tabular}{|c|c|c|}
\hline $\begin{array}{l}\text { 2-Retirar tampa e abertura } \\
\text { da caixa }\end{array}$ & $\begin{array}{l}\text {. Peso da tampa } \\
\text { Objectos em altura } \\
\text {. Partículas sólidas e águas } \\
\text { residuais } \\
\text {. Gases/vapores tóxicos }\end{array}$ & $\begin{array}{l}\text {. Postura incorrecta/Lesões } \\
\text { músculo-esqueléticas } \\
\text {. Queda de objectos } \\
\text {. Escorregamento } \\
\text {. Queda em altura } \\
\text {. Projecção de partículas sólidas e } \\
\text { águas residuais } \\
\text {. Inalação de gases/vapores } \\
\text { tóxicos }\end{array}$ \\
\hline $\begin{array}{l}\text { 3-Operações de limpeza e } \\
\text { manutenção à superfície }\end{array}$ & $\begin{array}{l}\text {. Superfícies sujas e escorregadias } \\
\text {. Mangueira sobre pressão } \\
\text {. Partículas e águas residuais } \\
\text {. Gases/vapores tóxicos } \\
\text {. Vibrações e ruído } \\
\text {. Carência de oxigénio } \\
\text {. Insectos e roedores } \\
\text {. Agentes patogénicos } \\
\text { máquinas e equipamentos em } \\
\text { mau estado e/ou desprotegidos } \\
\text {. Desnível da caixa }\end{array}$ & $\begin{array}{l}\text {. Accionamento inadvertido de } \\
\text { máquinas e equipamentos } \\
\text {. Escorregamento } \\
\text {. Queda em desnível } \\
\text {. Projecção da mangueira } \\
\text {. Projecção de partículas sólidas e } \\
\text { águas residuais } \\
\text { tóxicos } \\
\text {. Asfixia } \\
\text {. Entrada de agentes patogénicos } \\
\text { no organismo } \\
\text {. Lesões músculo-esqueléticas } \\
\text {. Surdez }\end{array}$ \\
\hline 4-Recolocar a tampa & $\begin{array}{l}\text { Queda de objectos } \\
\text {. Peso da tampa } \\
\text {. Desnível da caixa } \\
\text {. Superfícies sujas e escorregadias }\end{array}$ & $\begin{array}{l}\text { Postura incorrecta/Lesões } \\
\text { músculo-esqueléticas } \\
\text {. Escorregamento } \\
\text {. Queda em desnível } \\
\text {. Queda de objectos }\end{array}$ \\
\hline 5-Retirar a sinalização & $\begin{array}{l}\text {. Tráfego intenso } \\
\text {. Locais de visibilidade reduzida }\end{array}$ & . Atropelamento \\
\hline
\end{tabular}

Tabela A3 - Inspecção e desobstrução/limpeza de colectores sem apoio da viatura

\section{RESUMOS}

Este artigo apresenta um projecto de análise-formação-acção participativa, centrado nas condições de trabalho de um grupo de operadores do saneamento dos Serviços Municipalizados de Água e Saneamento (SMAS) de Oeiras e Amadora. Através da análise da actividade e dos registos dos acidentes de trabalho naquele sector, foi arquitectado o processo formativo segundo 
um modelo de alternância entre sessões teóricas expositivas, sessões de auto-análise apoiadas durante o trabalho e sessões de análise e discussão colectiva. o processo formativo terminou com uma sessão com a Administração, de discussão e negociação de propostas de transformação das condições de trabalho e de aplicação de procedimentos de segurança. Todas as sessões de formação foram transcritas permitindo uma análise detalhada do seu conteúdo, no que respeita às modalidades de discurso utilizadas e aos temas mais abordados no diálogo dos operadores. No ano que se seguiu à formação monitorizou-se a implementação dos compromissos assumidos pelas partes envolvidas no projecto e a sinistralidade do grupo de saneamento. Em conclusão é evidenciada a participação de todos os actores como agentes activos na promoção da segurança e transformação das condições de trabalho.

Este artículo presenta un proyecto de análisis-formación-acción participativa, centrándose en las condiciones de trabajo de un grupo de operadores del saneamiento de los Servicios Municipales de Agua y Saneamiento (SMAS) de Oeiras y Amadora. Al analizar la actividad y los informes de accidentes de trabajo en ese sector, el proceso de capacitación fue diseñado de acuerdo con un modelo de alternancia entre períodos de sesiones teóricas expositivas, sesiones de auto-análisis apoyadas durante el trabajo y sesiones de análisis y debate colectivo. El proceso de formación concluyó con una reunión con la Administración, para discusión y negociación de propuestas para cambiar las condiciones de trabajo y aplicación de procedimientos de seguridad. Todas las sesiones fueron transcritas, lo que permite un análisis detallado de su contenido. En el año seguido a la formación, se ha supervisado el cumplimiento de los compromisos por las partes implicadas en el proyecto y los accidentes de trabajo del grupo de saneamiento. En conclusión se evidencia la participación de todos los actores como agentes activos en la promoción de la seguridad y la transformación de las condiciones de trabajo.

Cet article présente un projet d'analyse-formation-action participative en mettant l'accent sur les conditions de travail d'un groupe d'opérateurs du secteur d'assainissement d'un Service Municipal. En analysant l'activité de travail et les accidents de travail dans ce secteur, le processus de formation a été conçu selon un modèle alternant des sessions d'exposés théoriques, des sessions centrées sur l'auto-analyse organisées au cours de la journée de travail et des sessions d'analyse et de discussion collectives. Le processus de formation a été clôturé par une session avec l'Administration, afin que soient débattues et négociées des propositions visant à modifier les conditions de travail et la mise en œuvre de procédures de sécurité. Toutes les sessions de formation ont été retranscrites, permettant une analyse détaillée de leur contenu pour ce qui relevait des modalités des discours et des thèmes abordés. Au cours de l'année qui a suivi la formation, un suivi a été mis en place afin d'accompagner les engagements pris par les partenaires impliqués dans le projet et l'évolution des accidents de travail du secteur. En conclusion, l'intervention a mis en évidence les potentialités d'une participation des salariés en tant qu'agents actifs dans le cadre d'une stratégie de promotion de la sécurité et de la transformation des conditions de travail.

This article presents a participative analysis-training-action project, aimed at promoting working conditions in a group of sanitation workers belonging to the Water Municipal Services of Oeiras and Amadora (SMAS). Using the activity analysis and records of work related accidents in that sector, we designed an alternating session's model training process based on a model alternating between theoretical expositive sessions and sessions of self-analysis, supported during work, and sessions of collective analysis and discussion. The training process ended with a session with the Administration, discussing and negotiating proposals for changing working conditions and implementing safety behaviours. All training sessions were recorded allowing for a thorough examination of their contents, concerning the used speech mode and the most broached subjects in the dialogue with the operators. In the year following the training sessions 
we monitored the implementation of the assumed commitments by the involved parties in the project and the accidents that occurred in the sanitation group. In short we established the participation of all people involved as active agents in the promotion of safety and change in working conditions.

\section{ÍNDICE}

Mots-clés: analyse du travail, transformation du travail, formation contextualisée, auto-analyse du travail, assainissement

Palavras-chave: análise do trabalho, formação contextualizada, auto-análise do trabalho, transformação do trabalho, saneamento

Keywords: work analysis, contextualized training, work self-analysis, work transformation, sanitation

Palabras claves: análisis del trabajo, transformación del trabajo, formación contextualizada, auto-análisis del trabajo, saneamiento

\section{AUTORES}

\section{CLÁUDIA COSTA}

Serviços Municipalizados de Água e Saneamento de Oeiras e Amadora - Av. Dr. Francisco Sá Carneiro, 19. 2784 - 541 Oeiras

cfcosta@smas-oeiras-amadora.pt

\section{CATARINA SILVA}

Faculdade de Motricidade Humana - Estrada da Costa. 1495-688 Cruz Quebrada - Dafundo csilva@fmh.utl.pt 